\title{
Field Control of Bacterial Spot and Bacterial Speck of Tomato Using a Plant Activator
}

F. J. Louws, Department of Plant Pathology, North Carolina State University, Raleigh 27695-7616; M. Wilson and H. L. Campbell, Department of Plant Pathology, 209 Life Sciences Building, Auburn University, Auburn, AL 36849-5409; D. A. Cuppels, Agriculture and Agri-Food Canada, Southern Crop Protection and Food Research Centre, 1391 Sandford Street, London, ON, Canada N5V 4T3; J. B. Jones, 1453 Fifield Hall - Plant Pathology Department, P.O. Box 110680, Gainesville, FL 32611-0680; P. B. Shoemaker, Department of Plant Pathology, North Carolina State University, Fletcher 28732; and F. Sahin and S. A. Miller, Department of Plant Pathology, Ohio State University, Wooster 44691-4114

\begin{abstract}
Louws, F. J., Wilson, M., Campbell, H. L., Cuppels, D. A., Jones, J. B., Shoemaker, P. B., Sahin, F., and Miller, S. A. 2001. Field control of bacterial spot and bacterial speck of tomato using a plant activator. Plant Dis. 85:481-488.

Acibenzolar-S-methyl (CGA 245704 or Actigard 50WG) is a plant activator that induces systemic acquired resistance (SAR) in many different crops to a number of pathogens. Acibenzolar-S-methyl was evaluated for management of bacterial spot (Xanthomonas axonopodis pv. vesicatoria) and bacterial speck (Pseudomonas syringae pv. tomato) of tomato in 15 and 7 field experiments, respectively. Experiments were conducted over a 4-year period in Florida, Alabama, North Carolina, Ohio, and Ontario using local production systems. Applied at $35 \mathrm{~g}$ a.i. $\mathrm{ha}^{-1}$, acibenzolar-S-methyl reduced foliar disease severity in 14 of the 15 bacterial spot and all 7 bacterial speck experiments. Disease control was similar or superior to that obtained using a standard copper bactericide program. Acibenzolar- $S$-methyl also reduced bacterial fruit spot and speck incidence. Tomato yield was not affected by using the plant activator in the field when complemented with fungicides to manage foliar fungal diseases, but tomato transplant dry weight was negatively impacted. $X$. axonopodis pv. vesicatoria population densities on greenhouse-grown tomato transplants were reduced by acibenzolar- $S$-methyl treatment. Bacterial speck and spot population densities on leaves of field-grown plants were not dramatically affected. Acibenzolar- $S$-methyl can be integrated as a viable alternative to copper-based bactericides for field management of bacterial spot and speck, particularly where copper-resistant populations predominate.
\end{abstract}

Additional keywords: Bion, copper hydroxide, induced resistance, Xanthomonas campestris pv. vesicatoria, Xanthomonas vesicatoria

Bacterial spot, caused by Xanthomonas axonopodis pv. vesicatoria or $X$. vesicatoria (21), and bacterial speck, caused by Pseudomonas syringae pv. tomato, are economically important diseases of tomato (Lycopersicon esculentum Mill.) (19,37). These pathogens are commonly introduced on contaminated seed $(14,27,31,40)$ or may be endemic (20,31). Disease results in leaf lesions, defoliation, fruit lesions, and ultimately yield loss of marketable fruit. A low incidence of contaminated seed can lead to a high incidence of disease in the field as a result of epiphytic multiplication

Corresponding author: F. J. Louws

E-mail: frank_louws@ncsu.edu

Current address of M. Wilson: Biology Department, The Colorado College, Colorado Springs, CO 80903.

Accepted for publication 16 January 2001.

Publication no. D-2001-0301-01R

(C) 2001 The American Phytopathological Society and distribution of the pathogens in the tomato phyllosphere.

Management of bacterial spot and speck is a challenge in commercial production fields due to limited efficacy of current disease management strategies. Causal bacteria readily acquire resistance to streptomycin and fixed copper bactericides $(9,30,42)$, and host resistance has not proven durable (21). There are currently two known races of $X$. axonopodis pv. vesicatoria (T1 and $\mathrm{T} 3$ ) and one race of $X$. vesicatoria (T2) (21). Tomato host resistance to T1 (35) is not effective against T3 strains that have recently emerged as a predominant population in Florida (21), nor against T2 strains commonly found in the Midwest (28). Host resistance to all three races has been identified (36) in L. esculentum PI 114490, but this resistance has not been incorporated into commercial cultivars. In a similar manner, virulent strains of $P$. syringae pv. tomato lacking the avirulence gene avrPto were documented in natural populations (26) even prior to deployment of the Pto resistance gene (33).
Lack of efficacious pesticides and host resistance for management of foliar bacterial diseases of tomato has stimulated efforts to develop alternative strategies. One strategy includes the use of bioactive products, commonly referred to as "plant activators," that induce systemic acquired resistance (SAR) in plants to limit pathogenesis of many plant pathogens, including bacteria (43). Tobacco (Nicotiana tabacum L.), cucumber (Cucurbita pepo), and Arabidopsis thaliana have functioned as model plants to elucidate the biochemical, genetic, and molecular mechanisms of SAR, which appear to be widespread among plant species $(29,43)$. Acquired resistance in plants has been observed for many years and can be induced by necrotizing or incompatible pathogens, biological elicitors, and certain chemicals $(5,16,34,46)$.

The development of synthetic compounds that elicit plant defense reactions portends a new approach to field management of bacterial diseases. One such compound, acibenzolar- $S$-methyl (25) (CGA 245704, Actigard 50WG, Bion 50WG, Syngenta, Basel, Switzerland), meets the criteria (23) for a plant activator (i.e., the compound has no direct microbial activity but elicits plants to acquire preinfection biochemical processes that confer resistance to the same spectrum of pathogens as a biological elicitor). Acibenzolar- $S$-methyl induces SAR in numerous hosts to a wide range of pathogens $(2,3,11-13,15,17,18$, $32,39,41,45)$. SAR has proven effective in tomato against fungal $(3)$, oomycete $(2,6)$, and bacterial diseases (17), and has been associated with a cascade of defense reactions including the accumulation of pathogenesis-related (PR) proteins and ultrastructural changes $(3,6)$.

Acibenzolar- $S$-methyl has been studied as a principle component of disease management strategies in a limited number of field experiments $(11,15,17,41)$. The ability of acibenzolar- $S$-methyl to induce SAR in tomato led to our objective to determine field efficacy of this plant activator against bacterial spot and speck. Experiments were conducted according to regional production practices and protocols in Florida, Ala- 
bama, North Carolina, Ohio, and Ontario. Here we report on the efficacy of acibenzolar-S-methyl in eastern North America for control of bacterial spot and speck of tomato in diverse production systems.

\section{MATERIALS AND METHODS}

Field experiments. Field experiments were initiated in Florida, Alabama, North Carolina, Ohio, and Ontario, five sites that represent considerable diversity in tomato production systems across the eastern United States and Canada. The cultural system, cultivars grown, inoculum and inoculation methods, disease-rating method, and experimental designs are summarized in Table 1. A total of 15 and 7 field experiments for management of bacterial spot and speck of tomato, respectively, were conducted from 1996 to 1999 (Tables 2 and 3). Standard production practices for each region, including fertility, insect management, and irrigation, were followed. Greenhouse-grown tomato plants, 4 to 6 weeks old, were transplanted into each experimental field site, and bactericide or plant activator applications were initiated within 1 to 30 days after transplanting with a minimum of 7 days prior to challenge inoculation in cases where pathogen inoculum was applied.

Acibenzolar-S-methyl (Actigard 50WG) treatments were applied weekly at $35 \mathrm{~g}$ a.i./ha in Florida, Alabama, North Carolina, Ohio, and every 10 days in Ontario. Reduced rates of $17.5 \mathrm{~g}$ a.i./ha, higher rates of $70 \mathrm{~g}$ a.i./ha, and extended intervals of 14 days were also evaluated in several of the experiments. Plots not sprayed with any bactericide (controls) and plots sprayed with a standard copper program were included in each experiment except in Ontario and in experiment 21 in North Carolina, where a standard copper program was not included. The standard bactericide consisted of copper hydroxide tank-mixed with an EBDC or other protectant fungicide, as outlined below. In Florida, copper hydroxide (185 g a.i. per 100 liters; Kocide 101) plus mancozeb (144 g a.i. per 100 liters; Dithane M-45) was applied. In Alabama, copper hydroxide (2,066 g a.i./ha; Kocide DF $61.4 \%$ ) plus maneb (1,345 g a.i./ha; Manex) was used. For the bacterial spot experiments in North Carolina, copper hydroxide $(2,000 \mathrm{~g}$ a.i./ha; Kocide DF 61.4\%) plus maneb (1,681 g a.i./ha; 1996; Maneb $75 \mathrm{DF})$ or mancozeb $(1,681 \mathrm{~g}$ a.i./ha; 1997 to 1998; Dithane M-45) was used. In the bacterial speck experiment in North Carolina in 1999, standard weekly sprays were applied using mancozeb + copper hydroxide (mancozeb $84 \mathrm{~g}$ a.i. per 100 liters + copper hydroxide $259 \mathrm{~g}$ a.i. per 100 liters; ManKocide) compared with the acibenzolar- $S$-methyl treatment applied according to the following schedule: mancozeb (350 g a.i. per 100 liters; Dithane DF NT) in the first, second, fourth, sixth, and eighth applications; trifloxystrobin (15 g a.i. per 100 liters; Flint $50 \mathrm{WG}$ ) + acibenzolar- $S$-methyl (5 g a.i. per 100 liters; Actigard 50WG) in the third, fifth, seventh, ninth, eleventh, and thirteenth applications; and chlorothalonil (302 $\mathrm{g}$ a.i. per 100 liters; Bravo Ultrex 82.5 WDG) in the tenth and twelfth applications. Applications were made at $2 \times$ concentration, and spray volumes began at 140 liters/ha and were increased 93.5 liters/ha to a maximum of 702 liters/ha. This resulted in a rate of $35 \mathrm{~g}$ a.i./ha for acibenzolar- $S$-methyl using full volumes. Copper hydroxide (862 g a.i./ha; Kocide 77 WP) + mancozeb $(1,344 \mathrm{~g}$ a.i./ha; Penncozeb 75DF) in 1997 to 1998 or mancozeb (899 g a.i./ha; Dithane M-45) in 1999 was used in Ohio. In the bacterial spot experiments in Florida, Alabama, North Carolina, and Ohio, chlorothalonil or an EBDC fungicide was applied to the controls and acibenzolar- $S$-methyl-treated plots to limit foliar fungal diseases.

Foliar disease severity was assessed by direct counts or by estimating the percent leaf area affected by bacterial lesions using the Horsfall-Barratt rating scale (4). Disease severity was calculated in Alabama by counting the number of lesions per 20 leaflets collected from each row per plot and expressing as number of lesions per $\mathrm{cm}^{2}$ of leaflet area. In Ontario, disease severity was expressed as the mean number of lesions per 20-leaf sample with six 20leaf samples collected per replicate row for a total of 24 20-leaf samples per treatment. Foliar disease rating methods in each experiment are highlighted in Tables 2 and 3. Occurrence of fruit with bacterial spot or speck symptoms was expressed as a percentage of total harvested fruit weight or number. Total yield from each plot was

Table 1. Summary of site, year, and experimental parameters for evaluation of acibenzolar-S-methyl (Actigard 50WG) in tomato production systems

\begin{tabular}{|c|c|c|c|c|c|c|c|c|c|}
\hline \multirow[b]{2}{*}{ Location } & \multirow[b]{2}{*}{ Culture system $^{x}$} & \multicolumn{4}{|c|}{ Cultivar (experiment no.) } & \multirow{2}{*}{$\begin{array}{c}\text { Inoculum } \\
\text { or strain } \\
\text { designation }\end{array}$} & \multirow{2}{*}{$\begin{array}{l}\text { Inoculation } \\
\text { method }\end{array}$} & \multirow{2}{*}{$\begin{array}{l}\text { Disease } \\
\text { ratingy }\end{array}$} & \multirow[b]{2}{*}{ Plot design $^{z}$} \\
\hline & & 1996 & 1997 & 1998 & 1999 & & & & \\
\hline \multicolumn{10}{|c|}{ Fresh market tomatoes } \\
\hline Alabama & $\begin{array}{l}\text { Black plastic; } \\
\text { MB fumigation; } \\
\text { drip irrigation; } \\
\text { staked }\end{array}$ & $\begin{array}{l}\text { Agriset } 761 \\
(1,2)\end{array}$ & $\begin{array}{c}\text { Agriset } 761 \\
\text { (4, 16, 17) } \\
\text { Rutgers (3) }\end{array}$ & $\begin{array}{r}\text { Agriset } 761 \\
(5,18,19)\end{array}$ & $\cdots$ & $\begin{array}{l}\text { Pst PT12 } \\
\text { Xcv AD17 } \\
\text { (T1) }\end{array}$ & $\begin{array}{l}10^{8} \text { foliar spray } \\
\text { in } 30 \mathrm{mM} \\
\text { phosphate } \\
\text { buffer }\end{array}$ & $\begin{array}{l}\text { Lesion/20 } \\
\text { leaflets; \% } \\
\text { defoliation }\end{array}$ & $\begin{array}{c}\text { RCBD } 5 \text { blocks; } 10 \\
\text { plants per plot; } 50 \\
\times 120 \mathrm{~cm} \text { spacing }\end{array}$ \\
\hline Florida & $\begin{array}{l}1996 \text { white plastic; } \\
1997 \text { black plastic; } \\
\text { MB fumigation; } \\
\text { drip irrigation; } \\
\text { staked }\end{array}$ & $\begin{array}{l}\text { Agriset } 761 \\
\text { (14) }\end{array}$ & Sunbeam (15) & $\ldots$ & $\ldots$ & Xv 938 (T3) & $\begin{array}{l}10^{8} \text { foliar spray } \\
\text { in } 0.01 \mathrm{M} \\
\mathrm{MgSO}_{4} \text { buffer }\end{array}$ & $\mathrm{HB}$ & $\begin{array}{r}\text { RCBD } 4 \text { blocks; } 10 \\
\text { plants per plot; } 45 \\
\times 120 \mathrm{~cm} \text { spacing }\end{array}$ \\
\hline $\begin{array}{l}\text { North } \\
\text { Carolina }\end{array}$ & $\begin{array}{l}1996 \text { flat ground; } \\
\text { staked; overhead } \\
\text { irrigation; 1997-9 } \\
\text { black plastic; MB } \\
\text { fumigation; drip } \\
\text { irrigation; staked }\end{array}$ & $\begin{array}{l}\text { Solar Set } \\
\text { (7) Sun- } \\
\text { Leaper (8) }\end{array}$ & $\begin{array}{l}\text { Solar Set } \\
\text { SunLeaper } \\
(9)\end{array}$ & $\begin{array}{l}\text { Solar Set } \\
\text { SunLeaper } \\
\text { (10) Mt. } \\
\text { Fresh (21) }\end{array}$ & $\begin{array}{l}\text { Mt. Spring } \\
\text { (22) }\end{array}$ & $\begin{array}{l}\text { Xcv } 5(\mathrm{~T} 1) \\
\text { Xcv } 10(\mathrm{~T} 1) \\
\text { Pst is natu- } \\
\text { ral inocu- } \\
\text { lum }\end{array}$ & $\begin{array}{l}\text { Planted Xcv } \\
\text { infested plant } \\
\text { in middle of } \\
\text { each plot }\end{array}$ & $\begin{array}{l}\% \text { defolia- } \\
\text { tion; } \mathrm{HB}\end{array}$ & $\begin{array}{l}\text { RCBD } 4 \text { blocks ( } 5 \\
\text { blocks } 1998 \text { exp. } \\
\text { 10); } 9-12 \text { plants } \\
\text { per plot; } 45-60 \times \\
120 \mathrm{~cm} \text { spacing }\end{array}$ \\
\hline Ohio & $\begin{array}{l}\text { Processing tomatoes } \\
\text { Flat ground beds; } \\
\text { no fumigation }\end{array}$ & $\cdots$ & OH7814 (11) & $\begin{array}{l}\text { Peto } 696 \\
\text { (12) }\end{array}$ & $\begin{array}{l}\text { Peto } 696 \\
\text { (13) }\end{array}$ & $\begin{array}{l}\text { Xcv 110C } \\
\text { (97/98;T1P3) } \\
\text { Xcv 767 (99) }\end{array}$ & $\begin{array}{l}10^{8} \text { foliar spray } \\
\text { in distilled } \\
\text { water }\end{array}$ & $\mathrm{HB}$ & $\begin{array}{c}\text { RCBD } 4 \text { blocks; } 15 \\
\text { plants per plot; } 30 \\
\times 120 \mathrm{~cm} \text { spacing }\end{array}$ \\
\hline Ontario & $\begin{array}{l}\text { Flat ground beds; } \\
\text { no fumigation }\end{array}$ & $\cdots$ & H9478 $(6,20)$ & $\cdots$ & $\cdots$ & $\begin{array}{r}\text { Pst DCT6D1 } \\
\text { Xv DC96-1 }\end{array}$ & $\begin{array}{l}5 \times 10^{8} \text { foliar } \\
\text { spray in dis- } \\
\text { tilled water }\end{array}$ & $\begin{array}{l}\text { Lesions/20- } \\
\text { leaf sam- } \\
\text { ple }\end{array}$ & $\begin{array}{c}\text { RCBD } 6 \text { blocks; } 40 \\
\text { plants per plot; } 46 \\
\times 120 \mathrm{~cm} \text { spacing } \\
\end{array}$ \\
\hline
\end{tabular}

${ }^{\mathrm{x}} \mathrm{MB}=$ methyl bromide; fresh market tomato cultivars were used in Alabama, Florida, and North Carolina, and processing tomato cultivars were used in Ohio and Ontario.

${ }^{y} \mathrm{HB}=$ Horsfall-Barratt rating scale or modifications thereof to estimate percent leaves with bacterial lesions. Lesion/20 leaflets is 20 leaflets collected per row per plot and analyzed for number of lesions per $\mathrm{cm}^{2}$ of leaf area.

z The 1997 and 1998 North Carolina bacterial spot studies were split plots with spray treatment as main plots and variety (SunLeaper or Solar Set) as subplots. Interactions were not significant and only main plot effects are reported; RCBD = randomized complete block design. 
weighed in 19 of the 22 experiments and expressed as metric tonnes per hectare. To compare among experiments at the different sites, the total yield due to treatment effects was expressed as a percentage of the controls.

Field data were analyzed by analysis of variance, and means were separated by Duncan's multiple range tests or Fisher's least significant difference test at $P=0.05$. Although most experiments included more than three treatments, only the controls, acibenzolar- $S$-methyl at the $35 \mathrm{~g}$ a.i. rate, and standard bactericide treatments are reported in Tables 2 and 3.

Greenhouse experiments conducted in Ohio. A tomato cultivar susceptible to bacterial spot (OH8245 in 1996; Easy Harvest in 1997) was seeded directly (three seeds per pot) into 1.2-liter pots containing a commercial planting mix (BACCTO high porosity planting mix, Michigan Peat Co., Houston, TX) or seeded in 288-cell plug trays, then transplanted 4 weeks later to 1.2-liter pots containing the same mix (three seedlings per pot). Acibenzolar- $S$ methyl was applied at a rate of $35 \mathrm{~g}$ a.i./ha using a hand-held sprayer 1 and 2 weeks later. Control plants were treated with water. Plants were inoculated 1 day after the second acibenzolar-S-methyl treatment with $X$. axonopodis pv. vesicatoria race T1P8 strain 110c (streptomycin resistant) suspended in distilled water at $10^{8}$ $\mathrm{CFU} / \mathrm{ml}$. Inoculated plants were kept in a mist chamber (relative humidity $>90 \%$; $25^{\circ} \mathrm{C}$ ) for 30 to $36 \mathrm{~h}$, then transferred to a greenhouse bench until symptoms were assessed. Noninoculated plants were kept in a separate mist chamber under the same conditions.

Plants were rated for foliar symptoms 7 to 10 days after inoculation using the following scale: $1=$ symptomless; $2=\mathrm{a}$ few necrotic spots; 3 = many spots, some coalescing; 4 = severe spotting and defoliation; and 5 = plant dead. Experiments were conducted three times for each cultivar. Plant dry weight was assessed 3 to 4 weeks after the initial acibenzolar- $S$ methyl application. Data from the three experiments were combined and analyzed by analysis of variance (ANOVA) using Minitab statistical software (Minitab, Inc., State College, PA). Means were separated with Fisher's least significant difference test.

Table 2. Efficacy of the plant activator acibenzolar-S-methyl (Actigard 50WG) compared with controls and plots sprayed with a standard bactericide program to manage bacterial spot on tomato

\begin{tabular}{|c|c|c|c|c|c|c|}
\hline Exp. no. & Treatment & $\begin{array}{c}\text { Foliar severity of } \\
\text { bacterial spot }^{\mathrm{x}}\end{array}$ & $\begin{array}{c}\text { Fruit with } \\
\text { bacterial spot }^{\mathrm{x}}\end{array}$ & $\begin{array}{l}\text { Yield } \\
\mathrm{mt} / \mathrm{ha}\end{array}$ & $\begin{array}{c}\text { Yield } \\
\% \text { of control }\end{array}$ & Comments $^{y}$ \\
\hline \multirow[t]{3}{*}{1} & Control & 50.9 & $\ldots$ & 9.3 & & Auburn 1996 \\
\hline & Standard & 50.6 & $\ldots$ & 7.8 & 83.9 & Agriset 761 \\
\hline & Actigard & $42.5 * *$ & $\ldots$ & 10.3 & 110.8 & $\%$ defoliation \\
\hline \multirow[t]{3}{*}{2} & Control & 174.4 & 3.7 & $119.0^{\mathrm{z}}$ & & Auburn 1996 \\
\hline & Standard & $92.6 *$ & 3.3 & 77.0 & 64.7 & Agriset 761 \\
\hline & Actigard & $78.9 *$ & 2.6 & 83.5 & 70.2 & AUDPC \\
\hline \multirow[t]{3}{*}{3} & Control & 232.1 & $\ldots$ & 21.7 & & Auburn 1997 \\
\hline & Standard & $109.6 *$ & $\ldots$ & 38.0 & 175.1 & Rutgers \\
\hline & Actigard & $71.5 * *$ & $\ldots$ & 32.2 & 148.4 & AUDPC \\
\hline \multirow[t]{3}{*}{4} & Control & $1,346.7$ & $\ldots$ & $\ldots$ & & Auburn 1997 \\
\hline & Standard & $848.2 *$ & $\ldots$ & $\ldots$ & $\ldots$ & Agriset 761 \\
\hline & Actigard & $526.9 * *$ & $\ldots$ & $\ldots$ & $\ldots$ & AUDPC \\
\hline \multirow[t]{3}{*}{5} & Control & 692.6 & 29.4 & 31.3 & & Auburn 1998 \\
\hline & Standard & $411.3^{*}$ & 27.6 & 35.2 & 112.5 & Agriset 761 \\
\hline & Actigard & $334.4^{*}$ & $20.2 * *$ & 36.0 & 115.0 & AUDPC \\
\hline \multirow[t]{3}{*}{6} & Control & 239.7 & 30.0 & 59.5 & & Ontario 1997 \\
\hline & Standard & $\ldots$ & $\ldots$ & $\ldots$ & . & Heinz 9478 \\
\hline & Actigard & $76.8 *$ & 22.6 & 66.7 & 112.1 & lesions/20-leaf sample \\
\hline \multirow[t]{3}{*}{7} & Control & 254.0 & 47.0 & 21.6 & & North Carolina 1996 \\
\hline & Standard & $179.0 *$ & $29.0 *$ & 29.0 & 134.3 & Solar Set \\
\hline & Actigard & $129.0 * *$ & $26.0 *$ & 22.1 & 102.3 & AUDPC \\
\hline \multirow[t]{3}{*}{8} & Control & 169.0 & 39.0 & 55.2 & & North Carolina 1996 \\
\hline & Standard & $140.0^{*}$ & $20.0 *$ & 54.8 & 99.3 & SunLeaper \\
\hline & Actigard & $101.0^{*}$ & $15.0 *$ & 49.2 & 89.1 & AUDPC \\
\hline \multirow[t]{3}{*}{9} & Control & 205.7 & 16.2 & 44.6 & & North Carolina 1997 \\
\hline & Standard & $123.5^{*}$ & $6.7^{*}$ & 37.3 & 83.6 & Solar Set \& SunLeaper \\
\hline & Actigard & $147.7 *$ & $6.4^{*}$ & 43.0 & 96.4 & AUDPC \\
\hline \multirow[t]{3}{*}{10} & Control & $\ldots$ & 1.6 & 17.5 & & North Carolina 1998 \\
\hline & Standard & $\ldots$ & 0.0 & 18.6 & 106.3 & Solar Set \& SunLeaper \\
\hline & Actigard & $\ldots$ & 0.4 & 16.4 & 93.7 & AUDPC \\
\hline \multirow[t]{3}{*}{11} & Control & 111.8 & 1.5 & 49.4 & & Ohio 1997 \\
\hline & Standard & $56.8^{*}$ & 1.6 & 52.2 & 105.6 & OH7814 \\
\hline & Actigard & $63.3^{*}$ & 0.4 & 45.7 & 92.6 & AUDPC \\
\hline \multirow[t]{3}{*}{12} & Control & 33.3 & 14.0 & 37.9 & & Ohio 1998 \\
\hline & Standard & $6.3^{*}$ & $3.4^{*}$ & 44.1 & 116.4 & Peto 696 \\
\hline & Actigard & $5.0^{*}$ & $6.7 *$ & 27.7 & 73.1 & $\%$ disease 2 Sep \\
\hline \multirow[t]{3}{*}{13} & Control & 44.3 & $>0.1$ & 64.7 & & Ohio 1999 \\
\hline & Standard & $19.0 *$ & $>0.1$ & 71.1 & 109.9 & Peto 696 \\
\hline & Actigard & 26.1 & $>0.1$ & 59.7 & 92.3 & $\%$ disease $30 \mathrm{Aug}$ \\
\hline \multirow[t]{3}{*}{14} & Control & 97.8 & $\ldots$ & 40.4 & & Florida 1996 \\
\hline & Standard & $48.6^{*}$ & $\ldots$ & 43.7 & 108.2 & Agriset 761 \\
\hline & Actigard & $44.4^{*}$ & $\ldots$ & 31.9 & 79.0 & AUDPC \\
\hline \multirow[t]{3}{*}{15} & Control & 99.6 & $\ldots$ & 19.3 & & Florida 1997 \\
\hline & Standard & $76.4^{*}$ & $\ldots$ & 22.6 & 117.1 & Sunbeam \\
\hline & Actigard & $63.4 *$ & $\ldots$ & $18.5^{* * *}$ & 95.9 & AUDPC \\
\hline
\end{tabular}

${ }^{\mathrm{x}}$ Values followed by $*$ are significantly different $(P=0.05)$ than control plots; means followed by $* *$ are significantly $(P=0.05)$ different than the standard bactericide treatment and control plots based on Duncan's multiple range test (AL, FL, ON) and Fisher's protected least significant difference (OH, $\mathrm{NC})$.

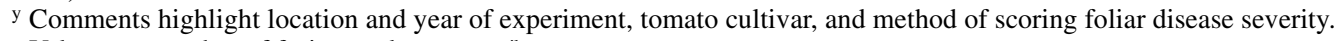

${ }^{\mathrm{z}}$ Values are number of fruit per plot, not $\mathrm{mt} / \mathrm{ha}$. 
Effect of bactericides on phyllosphere bacterial population densities. In the greenhouse experiments conducted in Ohio, bacterial population densities on the tomato foliage were determined by macerating three randomly selected leaves per pot in $1.0 \mathrm{ml}$ of a $0.1 \mathrm{M}$ phosphate buffer (pH 7.2) per gram of tissue and plating 10fold serial dilutions on sucrose peptone agar (SPA) medium amended with streptomycin sulfate at $50 \mathrm{mg} \mathrm{liter}{ }^{-1}$. Bacterial colonies were counted after 4 days of incubation at $28^{\circ} \mathrm{C}$, and $\log _{10}$ transformations of bacterial population densities were made prior to analysis.

$X$. axonopodis pv. vesicatoria and $P$. syringae pv. tomato bacterial population densities were also enumerated in the Ontario field experiments. Two 10-g leaflet samples were arbitrarily collected from the 40 plants of each treatment and each plot. Each 10-g sample was shaken in $100 \mathrm{ml}$ of sterile distilled water for $30 \mathrm{~min}$. Plant debris was removed by filtering the wash water through a glass-fiber filter (GF/A, Whatman). Bacteria were collected by centrifugation at $5,800 \times g$ for $15 \mathrm{~min}$ and then were resuspended in $5 \mathrm{ml}$ of sterile distilled water and plated on CKTM (40) agar to determine the $X$. axonopodis pv. vesicatoria population density and on Vogel-Bonner-tartrate medium (VBTar) (8) to determine the $P$. syringae pv. tomato population density. Colony lifts were made of the appropriate CKTM and VBTar dishes and hybridized with the $X$. $a x$ onopodis pv. vesicatoria probe KK1750
(24) or the $P$. syringae pv. tomato probe TPR1 (10). Probes had been DIG-labeled as previously described (24). Populations were monitored 5 June ( 5 days before the control agents were sprayed on the plants), 4 June, 15 July, and 5 and 26 August.

\section{RESULTS}

Control of bacterial spot. Acibenzolar$S$-methyl applied at $35 \mathrm{~g}$ a.i./ha reduced foliar bacterial spot compared with controls in 13 of the 15 experiments (Table 2). In experiment 10 , severity was not reported and acibenzolar- $S$-methyl did not reduce final foliar disease compared with the control in experiment 13. In the majority of experiments, the standard bactericide program applications also reduced foliar disease compared with controls. Acibenzolar$S$-methyl provided similar control of foliar bacterial spot as the standard bactericide program in seven experiments and was superior in three Alabama experiments (experiments 1, 3, and 4; Table 2) and one North Carolina experiment (experiment 7; Table 2).

In the experiments conducted in 1996 and 1997 in North Carolina (experiments 7 to 9), acibenzolar- $S$-methyl and the standard bactericide program decreased fruit spot incidence (Table 2). Likewise, acibenzolar- $S$-methyl decreased fruit spot incidence in 1998 at the sites in Auburn and Ohio (experiments 5 and 12) but had no significant effect in five other experiments where fruit spot occurred (experiments 2, $6,10,11$, and 13). Similar results were observed using the standard bactericide program.

In all experiments except the one in Florida in 1997 (experiment 15), total yield was not significantly affected by standard bactericide program or the plant activator, acibenzolar- $S$-methyl. The average total yields across all experiments were 109.0 and $97.9 \%$ for the standard bactericide program and acibenzolar-S-methyl, respectively, compared with controls. In the experiment in Florida in 1997, yield of extra large fruit was less in plots sprayed with acibenzolar- $S$-methyl than with the standard bactericide program (data not shown).

Control of bacterial speck. Acibenzolar- $S$-methyl reduced foliar bacterial speck compared with the controls and was similar or superior to the standard bactericide program (Table 3 ). In the experiment in North Carolina in 1999 (experiment 22), $P$. syringae pv. tomato strains were documented to be insensitive to copper (F. J. Louws and P. B. Shoemaker, unpublished), and weekly applications of copper increased symptoms of bacterial speck. Acibenzolar- $S$-methyl reduced fruit speck severity in Ontario in 1997 and in the experiments in North Carolina in 1998 and was superior to copper hydroxide but not the control in North Carolina in 1999 (Table 3). The use of fungicides (mancozeb in rotation with azoxystrobin) with no effective bactericide activity enhanced speck severity in North Carolina in 1998 (data not shown). Yield was not signifi-

Table 3. Efficacy of the plant activator acibenzolar-S-methyl (Actigard 50WG) compared with controls and plots sprayed with a standard bactericide program to manage bacterial speck on tomato

\begin{tabular}{|c|c|c|c|c|c|c|}
\hline Exp. no. & Treatment & $\begin{array}{l}\text { Foliar severity of } \\
\text { bacterial speck }^{v}\end{array}$ & $\begin{array}{c}\text { Fruit with } \\
\text { bacterial speck }^{v}\end{array}$ & $\begin{array}{l}\text { Yield } \\
\text { mt/ha }\end{array}$ & $\begin{array}{c}\text { Yield } \\
\% \text { of control }\end{array}$ & Comments $^{w}$ \\
\hline \multirow[t]{3}{*}{16} & Control & 1.3 & $\ldots$ & $\ldots$ & & Auburn 1997 \\
\hline & Standard & $1.1^{*}$ & $\ldots$ & $\ldots$ & $\ldots$ & Agriset 761 \\
\hline & Actigard & $1.0^{*}$ & $\ldots$ & $\ldots$ & $\ldots$ & Log no. lesions/leaflet \\
\hline \multirow[t]{3}{*}{17} & Control & 1.4 & $\ldots$ & $\ldots$ & & Auburn 1997 \\
\hline & Standard & $0.9^{*}$ & $\ldots$ & $\ldots$ & $\ldots$ & Agriset 761 \\
\hline & Actigard & $0.8^{* *}$ & $\ldots$ & $\ldots$ & $\ldots$ & Log no. lesions/leaflet \\
\hline \multirow[t]{3}{*}{18} & Control & 35.3 & $\ldots$ & $\ldots$ & & Auburn 1998 \\
\hline & Standard & 30.4 & $\ldots$ & $\ldots$ & $\ldots$ & Agriset 761 \\
\hline & Actigard $^{\mathrm{x}}$ & $22.6^{*}$ & $\cdots$ & $\cdots$ & $\begin{array}{l}\cdots \\
\cdots\end{array}$ & $\%$ final disease severity \\
\hline \multirow[t]{3}{*}{19} & Control & 44.3 & $\ldots$ & $\ldots$ & & Auburn 1998 \\
\hline & Standard & 26.1 & $\ldots$ & $\ldots$ & $\ldots$ & Agriset 761 \\
\hline & Actigard & $19.7 *$ & $\ldots$ & $\ldots$ & $\ldots$ & $\%$ final disease severity \\
\hline \multirow[t]{3}{*}{20} & Control & 45.0 & 22.6 & 87.8 & & Ontario 1997 \\
\hline & Standard & & & $\ldots$ & $\ldots$ & Heinz 9478 \\
\hline & Actigard & $10.5^{*}$ & $16.1^{*}$ & 83.2 & 94.8 & Lesions/20-leaf sample \\
\hline \multirow[t]{3}{*}{21} & Control & $\ldots$ & 9.2 & $17.3^{\mathrm{y}}$ & & North Carolina $1998^{z}$ \\
\hline & Standard & $\ldots$ & $\ldots$ & $\ldots$ & $\ldots$ & Mountain Fresh (foliar \\
\hline & Actigard & $\ldots$ & $1.4 * *$ & $12.6 * *$ & 72.8 & incidence not rated) \\
\hline \multirow[t]{3}{*}{22} & Control & 2.1 & 12.5 & $22.7^{y}$ & & North Carolina 1999 \\
\hline & Standard & $5.3 *$ & $21.1 *$ & 21.2 & 93.4 & Mountain Spring \\
\hline & Actigard & $0.0^{* *}$ & 7.0 & $29.5 * *$ & 130.0 & $\%$ leaf area damaged \\
\hline
\end{tabular}

${ }^{v}$ Values followed by $*$ are significantly different $(P=0.05)$ than control plots; means followed by $* *$ are significantly $(P=0.05)$ different than the standard bactericide treatment and control plots based on Duncan's multiple range test (AL, FL, ON) and Fisher's protected least significant difference (OH, $\mathrm{NC})$.

${ }^{\mathrm{w}}$ Comments highlight location and year of the experiment, tomato cultivar, and method of scoring foliar disease severity.

x Acibenzolar- $S$-methyl rate was $26.3 \mathrm{~g}$ a.i./ha, not $35 \mathrm{~g}$ a.i./ha.

${ }^{y}$ Marketable yield.

${ }^{\mathrm{z}}$ Acibenzolar-S-methyl was applied alone without any fungicides; final percent defoliation due to early blight, late blight, and bacterial speck was $88.9 \%$ in plots not sprayed, $85.4 \%$ in acibenzolar-S-methyl sprayed plots, and 5.3\% in the fungicide only plots (mancozeb alternated with azoxystrobin; no bactericide). 
cantly reduced in the Ontario experiment, but application of acibenzolar- $S$-methyl alone in North Carolina in 1998 resulted in substantially reduced marketable yield. Acibenzolar-S-methyl had no measurable effect on early blight nor late blight in this experiment, and no fungicides were applied to these plots. Final percent defoliation due to early blight, late blight, and bacterial speck was $88.9 \%$ for controls, $85.4 \%$ in acibenzolar- $S$-methyl sprayed plots, and $5.3 \%$ in the standard fungicidetreated plots (data not shown). Thus, for the experiment conducted in 1998, the direct effect of acibenzolar- $S$-methyl on crop yield could not be separated from yield loss due to defoliation caused by the fungal pathogens. In 1999, acibenzolar-Smethyl was integrated with standard fungicides, resulting in reduced severity of bacterial speck and effective management of the foliar fungal pathogens, translating into superior yields (Table 3 ).

Effect of acibenzolar- $S$-methyl rate on tomato bacterial spot and speck severity. Five experiments included evaluation of acibenzolar-S-methyl rates of $17.5,35.0$, or $70.0 \mathrm{~g}$ a.i./ha. Three experiments suggested the $17.5 \mathrm{~g}$ a.i. rate compromised control compared with the $35 \mathrm{~g}$ a.i. rate early in the disease epidemic based on foliar disease ratings but had no effect on final foliar disease severity, fruit spot or speck incidence, and yield (experiment 1, 3, 16; data not shown). Two experiments (experiments 7 and 8; data not shown) demonstrated there was no advantage to use of $70 \mathrm{~g}$ a.i./ha compared with $35 \mathrm{~g}$ a.i./ha.

Effect of acibenzolar- $S$-methyl in combination with standard bactericides. These experiments were designed to examine the hypothesis that acibenzolar- $S$ methyl would additively interact with copper hydroxide to provide superior control of bacterial diseases compared with acibenzolar-S-methyl or copper hydroxide alone. Ten experiments included this tankmix combination (data not shown). These experiments demonstrated acibenzolar- $S$ methyl used alone was as effective as the combination treatment, and the combination program was additively superior to a standard bactericide program in 3 of the 10 experiments.

Ohio greenhouse experiments. Since bacterial diseases of tomato often develop during transplant production in the greenhouse, experiments were designed to evaluate the utility of acibenzolar- $S$-methyl during early stages of plant growth (Table 4). The incidence of bacterial spot was reduced with acibenzolar- $S$-methyl in the greenhouse after inoculation with $X$. $a x$ onopodis pv. vesicatoria compared with the untreated control (Table 4). However, plants treated with acibenzolar- $S$-methyl were visibly smaller. For example, the dry weight of uninoculated Easy Harvest plants treated with acibenzolar-S-methyl was an average of $5.4 \mathrm{~g}$, compared with $10.7 \mathrm{~g}$ per untreated plant, a reduction of $50 \%$ (data not shown; $P=0.05$ ).

Effect of acibenzolar- $S$-methyl on phyllosphere pathogen population densities. Very little is known about the impact acibenzolar- $S$-methyl has on pathogenic bacterial populations. Total pathogen population densities were recorded in the greenhouse experiments in Ohio (Table 4), and epiphytic bacterial populations were recorded in two experiments in Ontario (experiments 6 and 20). In the seedling tests in Ohio, the log of total CFU per gram fresh weight of tomato tissue was reduced nearly two orders of magnitude (Table 4). The effect on epiphytic populations in the field in Ontario was less dramatic. $X$. axonopodis pv. vesicatoria and the $P$. syringae pv. tomato populations on tomato were slightly reduced or not affected by acibenzolar- $S$-methyl treatment compared with controls, depending on time of sampling (Fig. 1A and B).

\section{DISCUSSION}

Acibenzolar-S-methyl (Actigard 50WG) effectively controlled bacterial spot and speck of tomato in five regions in eastern North America. Acibenzolar-S-methyl applied at an optimum rate of $35 \mathrm{~g}$ a.i./ha on a 7- to 14-day schedule consistently reduced bacterial spot foliar disease severity in 13 of 15 experiments, reduced or did not affect fruit spot incidence, and did not impact total yield in 13 of 15 experiments compared with controls. Acibenzolar- $S$ methyl applied at $35 \mathrm{~g}$ a.i./ha was effective for the control of bacterial speck in seven experiments, similar to observations as described for the bacterial spot experiments. In all cases, acibenzolar- $S$-methyl was similar or superior to a standard bactericide spray program to limit foliar disease severity and bacterial fruit spot and speck incidence. A weekly spray program using a reduced rate of $17.5 \mathrm{~g}$ a.i./ha compromised control of foliar disease early in the epidemic but provided control similar to the $35 \mathrm{~g}$ a.i./ha rate by the end of the season. A high rate of $70 \mathrm{~g}$ a.i./ha offered no additional disease control advantage compared with the $35 \mathrm{~g}$ a.i./ha rate. Combining aci-
benzolar-S-methyl with copper hydroxide as a tank-mix did not offer superior control of bacterial spot or speck compared with using acibenzolar- $S$-methyl alone. Based on these experiments, acibenzolar- $S$ methyl should prove to be an effective new tool for tomato growers to manage bacterial spot and speck of tomatoes, with some precautions as outlined below.

Acibenzolar- $S$-methyl is likely to be of greatest benefit in fields where copperresistant strains of $X$. axonopodis pv. vesicatoria or $P$. syringae pv. tomato predominate. In the experiments highlighted here with the exception of strain Pst DCT6D1 in Ontario, copper-sensitive strains were used to inoculate plots, and in the majority of cases, copper was as effective as acibenzolar-S-methyl. However, copper-resistant strains can be common in natural epidemics $(9,22,30)$, and in some cases, weekly applications of copper hydroxide appear to aggravate bacterial disease severity (P. B. Shoemaker and F. J. Louws, unpublished data). In the North Carolina experiment in 1999 where copper-resistant strains were documented to predominate, acibenzolar- $S$ methyl provided superior control compared with a standard fungicide program that included copper hydroxide. Unlike copper, acibenzolar- $S$-methyl is not toxic to plant pathogens $(11,12)$. This is consistent with the limited impact repeated applications had on X. axonopodis pv. vesicatoria and $P$. syringae pv. tomato phyllosphere population densities in Ontario.

In most cases, the experiments in this study relied on introduced inoculum to achieve disease pressure. Typically, inoculum was applied no sooner than 7 days after the initial application of acibenzolar$S$-methyl. Acibenzolar-S-methyl requires approximately 4 days to activate plant defense mechanisms before acquired resistance is functional $(3,39)$. Such a short time frame should not pose a problem for using acibenzolar- $S$-methyl in commercial settings. Once activated, acquired resistance can be functional for extended periods of time, if not the entire season, in monocot plants against a range of pathogens $(15,32)$. This extended protection has not been observed in dicot plants, thus the

Table 4. Effect of acibenzolar-S-methyl on development of bacterial spot symptoms and pathogen population densities on tomato (OH8245 and Easy Harvest) seedlings after inoculation with Xanthomonas axonopodis pv. vesicatoria

\begin{tabular}{|c|c|c|c|}
\hline \multirow[b]{2}{*}{ Treatment } & \multicolumn{2}{|c|}{ OH8245 (1996) } & \multirow{2}{*}{$\begin{array}{c}\text { Easy harvest (1997) } \\
\text { Disease severity }^{\mathbf{x}, y}\end{array}$} \\
\hline & Disease severity $^{\mathrm{x}, \mathrm{y}}$ & $\log _{10} z$ & \\
\hline Control & $3.8 \mathrm{a}$ & $8.5 \mathrm{a}$ & $2.6 \mathrm{a}$ \\
\hline Acibenzolar-S-methyl & $1.3 \mathrm{~b}$ & $6.0 \mathrm{~b}$ & $1.0 \mathrm{~b}$ \\
\hline Uninoculated control & 1.0 & 0.0 & 1.0 \\
\hline
\end{tabular}

${ }^{x}$ Disease severity: 1 = symptomless; 2 = a few necrotic spots; 3 = many spots, some coalescing; 4 = severe spotting and defoliation; and 5 = plant dead.

${ }^{\mathrm{y}}$ Means in the same column followed by a different number are significantly different $(P=0.05)$ according to Duncan's multiple range test. Data for uninoculated controls were not included in the analysis.

${ }^{\mathrm{z}} \mathrm{Log}_{10}$ population (CFU/g tissue fresh weight) of $X$. axonopodis pv. vesicatoria recovered from tomato leaves. 
7- to 14-day schedule adopted in this study for tomatoes.

Although only a limited amount of research has been published on tomatoes, acibenzolar- $S$-methyl is known to induce rapid and coordinated expression of SARassociated genes. Subsequent physiological, biochemical, and ultrastructural changes in monocot and dicot plants are associated with induced resistance to a wide range of plant pathogens $(2,3,12$, 15,32). These studies highlight that the mechanisms of plant defense induced by plant activators require considerable physiological and biochemical changes. The implication of coordinated defense responses in commercial tomato production settings has not been thoroughly addressed. Ecological studies suggest there is a plant fitness cost to acquired resistance in the absence of pest pressure $(1,44,47)$. In particular, plants appear to favor induced host defense mechanisms over and above constitutive processes under low $\mathrm{N}$ levels (44). Thus, use of plant activators under crop stress conditions may induce plants to mount defense responses at the expense of constitutive growth requirements resulting in phytotoxicity. Phytotoxicity has been noted in pepper (S. A. Miller, unpublished; D. A. Cuppels, unpublished), burley tobacco (38), and flue cured tobacco seedlings (7). In the latter case, the phytotoxicity appeared as scattered necrotic spots and slight chlorosis but was overcome by increasing the volume of water used during application and top dressing with calcium nitrate (7). Leaf deformation and stunting was also noted with green beans exposed to high concentrations (greater than 0.4 $\mathrm{mmol} /$ liter) but not at the lower concentrations that afforded protection against several fungal and a bacterial disease (39). The energy cost associated with inducing

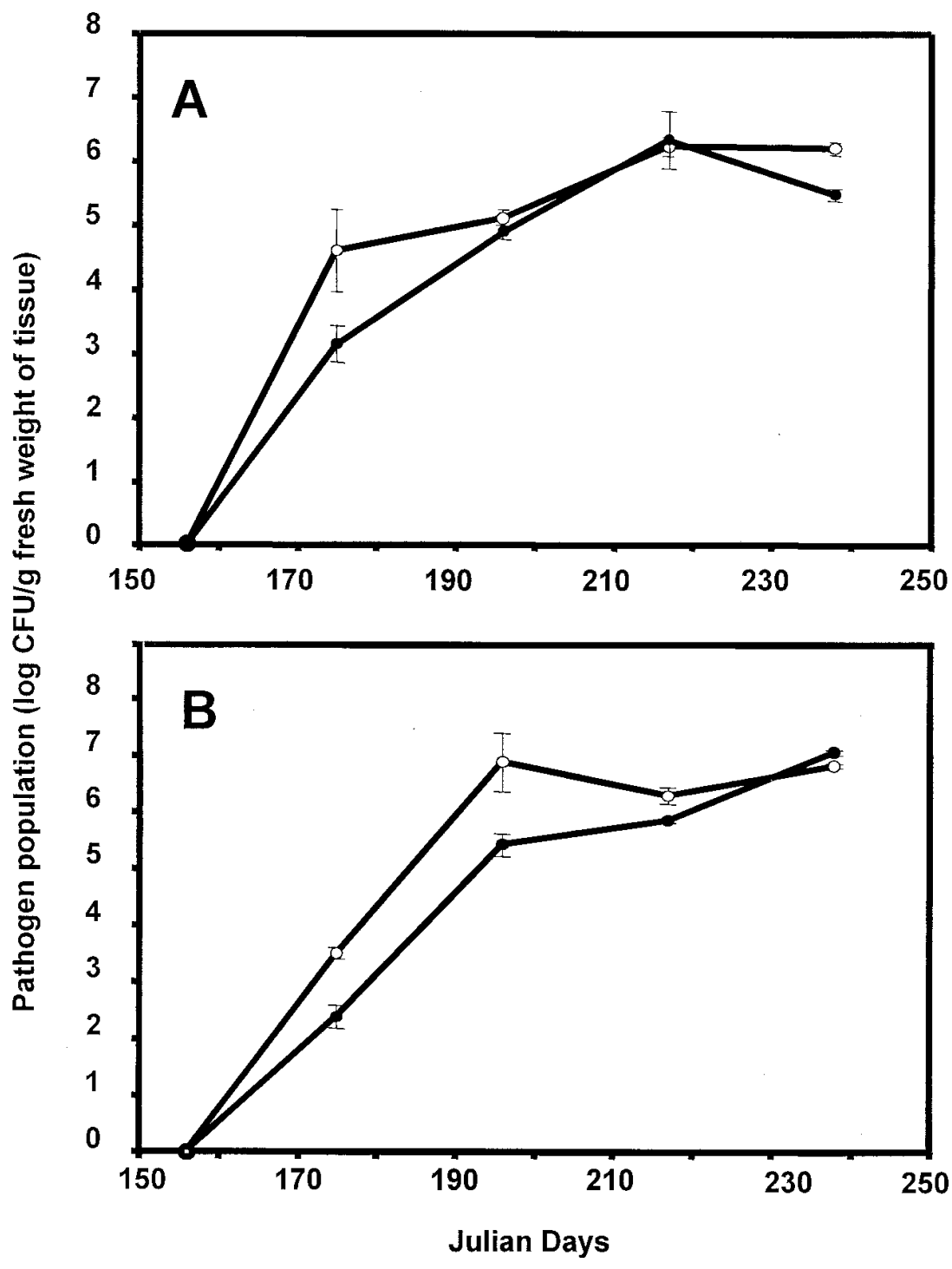

Fig. 1. A, Xanthomonas axonopodis pv. vesicatoria pathogen population densities on tomato leaves sprayed with acibenzolar-S-methyl (closed circles) or water (open circles). B, Pseudomonas syringae pv. tomato pathogen population densities on tomato leaves sprayed with acibenzolar- $S$-methyl (closed circles) or water (open circles). Vertical bars indicate standard error of the mean. defense responses may not be the sole or primary mechanism by which phytotoxicity occurs. Wild type and niml mutant Arabidopsis plants exhibited the same phytotoxicity symptoms when treated with high levels of acibenzolar-S-methyl. While the mutants cannot activate SAR in response to inducing pathogens or chemical activators, the mutants and the wild type both show phytotoxicity symptoms at the same concentration of inducer, suggesting a decoupling of phytotoxicity and SAR (K. Lawton, personal communication). This also may suggest that phytotoxicity is a function of host genetics and explain why extreme phytotoxicity is observed in peppers (S. A. Miller, unpublished; D. A. Cuppels, unpublished), a slight toxicity in tobacco $(7,38)$, and little to no acute phytotoxicity in field tomatoes (this study).

Despite the occurrence of no acute phytotoxicity in field grown tomatoes, there was reduced plant growth observed in the transplant experiments in Ohio. Additional work is needed to effectively use acibenzolar-S-methyl during transplant production, a critical stage during which the bacterial spot and speck pathogens multiply and spread. There also was a statistically nonsignificant but numerically consistent lower yield in the majority of bacterial spot tomato plots treated with acibenzolar- $S$ methyl compared with those treated with the standard fungicide program. We observed that acibenzolar- $S$-methyl had little activity against Alternaria solani (early blight) and Phytophthora infestans (late blight) in our experiments. This was most pronounced in the bacterial speck trial in North Carolina in 1998, where final percent defoliation was dramatically impacted by early blight and late blight and not reduced substantially by acibenzolar- $S$ methyl treatments, compared with the control plots (Table 3, footnote). However, even where the foliar fungal pathogens were managed using protectant fungicides, yields in standard fungicide plots averaged over all the spot experiments were $109 \%$ of the control plots, but $97.9 \%$ in acibenzolar$S$-methyl treated plots, a difference of $11 \%$ (normalized as percent control). The differences were not statistically significant but observed in most of the experiments. To limit such repression of yield, the number of applications and amount of product applied may need to be further optimized. This was the intent of the bacterial speck trial in North Carolina in 1999. Acibenzolar- $S$-methyl was applied at $2 \times$ concentration on a volume basis, beginning with 140 liters of water per hectare when plants were small and then increasing weekly up to 702 liters/ha at full plant growth. Foliar fungicides were included weekly, and acibenzolar- $S$-methyl was applied every 14 days (as described above). Integrating foliar fungicides with acibenzolar- $S$-methyl and limiting the number and total amount (on a hectare basis) of acibenzolar- $S$ - 
methyl applied significantly reduced bacterial speck incidence on the foliage and fruit and increased marketable yield. Such strategies will likely be adopted for successful commercial recommendations. Additional work may also elucidate the potential to set thresholds or forecast for the initial application to manage bacterial spot and speck.

Acibenzolar- $S$-methyl promises to be an important and viable tool to manage bacterial spot and speck of tomato. Additional work on timing and rates should help to fine tune the utility of acibenzolar- $S$ methyl as a disease management tool in the greenhouse and field. Activation of SAR, particularly in young tomato plants, for management of foliar bacterial diseases may require integrated knowledge of acibenzolar- $S$-methyl application recommendations, host plant growth stage and physiological status, and environmental conditions, particularly stress conditions (29). SAR is considered broad spectrum and general in efficacy and therefore would not be expected to result in differential control of different bacterial races or bactericide-resistant and -sensitive bacterial pathogens. Currently, management of bacterial diseases of tomato is inadequate, and our experiments highlight the potential of acibenzolar- $S$-methyl across many different production systems and disease pressure conditions. Furthermore, acibenzolar- $S$ methyl may also induce SAR effective against other tomato diseases $(3,17)$ not included in our experiments, increasing the potential benefit of this new disease management tool.

\section{ACKNOWLEDGMENTS}

We thank Jim Driver and R. O. Kelly for their valuable assistance during this study. Financial support for experiments in Alabama, North Carolina, and Florida was provided by a Southern Region IPM Grant (USDA n97-34103-4888) awarded to M. Wilson, J. B. Jones, E. J. Sikora, and F. J. Louws.

\section{LITERATURE CITED}

1. Baldwin, I. T. 1998. Jasmonate-induced responses are costly but benefit plants under attack in native populations. Proc. Natl. Acad. Sci. U.S.A. 95:8113-8118.

2. Benhamou, N., and Belanger, R. R. 1998. Induction of systemic resistance to Pythium damping-off in cucumber plants by benzothiadiazole: Ultrastructure and cytochemistry of the host response. Plant J. 14:13-21.

3. Benhamou, N., and Belanger, R. R. 1998. Benzothiadiazole-mediated induced resistance to Fusarium oxysporum f. sp. radicislycopersici in tomato. Plant Physiol. 118:1203-1212.

4. Campbell, C. L., and Madden, L. V. 1990. Introduction to Plant Disease Epidemiology. John Wiley \& Sons, New York.

5. Chester, K. S. 1933. The problem of acquired physiological immunity in plants. Quart. Rev. Biol. 8:275-324.

6. Cohen, Y., Niderman, T., Mosinger, E., and Fluhr, R. 1994. Beta-aminobutyric acid induces the accumulation of pathogenesisrelated proteins in tomato (Lycopersicon esculentum L.) plants and resistance to late blight infection caused by Phytophthora in- festans. Plant Physiol. 104:59-66.

7. Cole, D. L. 1999. The efficacy of acibenzolar$S$-methyl, an inducer of systemic acquired resistance, against bacterial and fungal diseases of tobacco. Crop Prot. 18:267-273.

8. Cuppels, D. A. 1986. Generation and characterization of Tn5 insertion mutations in Pseudomonas syringae pv. tomato. Appl. Environ. Microbiol. 51:323-327.

9. Cuppels, D. A., and Elmhirst, J. 1999. Disease development and changes in the natural Pseudomonas syringae pv. tomato populations on field tomato plants. Plant Dis. 83:759-764.

10. Cuppels, D. A., Moore, R. A., and Morris, V. L. 1990. Construction and use of a nonradioactive DNA hybridization probe for detection of Pseudomonas syringae pv. tomato on tomato plants. Appl. Environ. Microbiol. 56:1743-1749.

11. Dann, E., Diers, B., Byrum, J., and Hammerschmidt, R. 1998. Effect of treating soybean with 2,6-dichloroisonicotinic acid (INA) and benzothiadiazole (BTH) on seed yields and the level of disease caused by Sclerotinia sclerotiorum in field and greenhouse studies. Eur. J. Plant Pathol. 104:271-278.

12. Friedrich, L., Lawton, K., Ruess, W., Masner, P., Specker, N., Rella, M. G., Meier, B., Dincher, S., Staub, T., Uknes, S., Metraux, J. P., Kessmann, H., and Ryals, J. 1996. A benzothiadiazole derivative induces systemic acquired resistance in tobacco. Plant J. 10:6170.

13. Godard, J. F., Ziadi, S., Monot, C., Le Corre, D., and Silue, D. 1999. Benzothiadiazole (BTH) induces resistance in cauliflower (Brassica oleracea var. botrytis) to downy mildew of crucifers caused by Peronospora parasitica. Crop Prot. 18:397-405.

14. Goode, M. J., and Sasser, M. 1980. Prevention - The key to controlling bacterial spot and bacterial speck of tomato. Plant Dis. 64:831-834.

15. Gorlach, J., Volrath, S., Knaufbeiter, G., Hengy, G., Beckhove, U., Kogel, K. H., Oostendorp, M., Staub, T., Ward, E., Kessmann, H., and Ryals, J. 1996. Benzothiadiazole, a novel class of inducers of systemic acquired resistance, activates gene expression and disease resistance in wheat. Plant Cell 8:629643.

16. Hammerschmidt, R., and Kuc, J., eds. 1995. Induced resistance to disease in plants. Kluwer Scientific Publishers, Dordrecht, Netherlands.

17. Inbar, M., Doostdar, H., Sonoda, R. M., Leibee, G. L., and Mayer, R. T. 1998. Elicitors of plant defensive systems reduce insect densities and disease incidence. J. Chem. Ecol. 24:135-149.

18. Jensen, B. D., Latunde-Dada, A. O., Hudson, D., and Lucas, J. A. 1998. Protection of Brassica seedlings against downy mildew and damping-off by seed treatment with CGA 245704 , an activator of systemic acquired resistance. Pestic. Sci. 52:63-69.

19. Jones, J. B., Jones, J. P., Stall, R. E., and Zitter, T. A. 1991. Compendium of Tomato Diseases. American Phytopathological Society, St. Paul, MN.

20. Jones, J. B., Pohronezny, K. L., Stall, R. E., and Jones, J. P. 1986. Survival of Xanthomonas campestris pv. vesicatoria in Florida on tomato crop residue, weeds, seeds, and volunteer tomato plants. Phytopathology 76:430-434.

21. Jones, J. B., Stall, R. E., and Bouzar, H. 1998. Diversity among xanthomonads pathogenic on pepper and tomato. Annu. Rev. Phytopathol. 36:41-58.

22. Jones, J. B., Woltz, S. S., Jones, J. P., and Portier, K. L. 1991. Population dynamics of
Xanthomonas campestris pv. vesicatoria on tomato leaflets treated with copper bactericides. Phytopathology 81:714-719.

23. Kessmann, H., Staub, T., Ligon, J., Oostendorp, M., and Ryals, J. 1994. Activation of systemic acquired disease resistance in plants. Eur. J. Plant Pathol. 100:359-369.

24. Kuflu, K. M., and Cuppels, D. A. 1997. Development of a diagnostic DNA probe for xanthomonads causing bacterial spot of peppers and tomatoes. Appl. Environ. Microbiol. 63:4462-4470

25. Kunz, W., Schurter, R., and Maetzke, T. 1997. The chemistry of benzothiadiazole plant activators. Pestic. Sci. 50:275-282.

26. Lawton, M. B., and MacNeill, B. H. 1986. Occurrence of race 1 of Pseudomonas syringae pv. tomato on field tomato in southwestern Ontario. Can. J. Plant Pathol. 8:85-88.

27. Leite, R. P., Jones, J. B., Somodi, G. C., Minsavage, G. V., and Stall, R. E. 1995 Detection of Xanthomonas campestris pv. vesicatoria associated with pepper and tomato seed by DNA amplification. Plant Dis. 79:917-922.

28. Louws, F. J., Fulbright, D. W., Stephens, C. T., and de Bruijn, F. J. 1995. Differentiation of genomic structure by rep-PCR fingerprinting to rapidly classify Xanthomonas campestris pv. vesicatoria. Phytopathology 85:528536.

29. Lucas, J. A. 1999. Plant immunisation: From myth to SAR. Pestic. Sci. 55:193-196.

30. Marco, G. M., and Stall, R. E. 1983. Control of bacterial spot of pepper initiated by strains of Xanthomonas campestris pv. vesicatoria that differ in sensitivity to copper. Plant Dis. 67:779-781.

31. McCarter, S. M., Jones, J. B., Gitaitis, R. D., and Smitley, D. R. 1983. Survival of Pseudomonas syringae pv. tomato in association with tomato seed, soil, host tissue, and epiphytic weed hosts in Georgia. Phytopathology 73:1393-1398

32. Morris, S. W., Vernooij, B., Titatarn, S., Starrett, M., Thomas, S., Wiltse, C. C., Frederiksen, R. A., Bhandhufalck, A., Hulbert, S., and Uknes, S. 1998. Induced resistance responses in maize. Mol. Plant-Microbe Interact. 11:643-658.

33. Pitblado, R. E., and Kerr, E. A. 1979. A source of resistance to bacterial speck - Pseudomonas tomato. Tomato Genet. Coop. Rep. 9:30.

34. Ross, F. A. 1961. Systemic acquired resistance induced by localized virus infections in plants. Virology 14:340-358.

35. Scott, J. W., and Jones, J. B. 1986. Sources of resistance to bacterial spot in tomato. HortScience 21:304-306.

36. Scott, J. W., Miller, S. A., Stall, R. E., Jones, J. B., Somodi, G. C., Barbosa, V., Francis, D. L., and Sahin, F. 1997. Resistance to race T2 of the bacterial spot pathogen in tomato. HortScience 32:724-727.

37. Sherf, A. F., and MacNab, A. A. 1986. Vegetable Diseases and Their Control, 2nd ed. John Wiley \& Sons, New York.

38. Shoemaker, P. B. 1998. Evaluation of fungicides and application strategies for tobacco blue mold at Laurel Springs, NC, 1996. Fungic. Nematicide Tests 53:378.

39. Siegrist, J., Glenewinkel, D., Kolle, C., and Schmidtke, M. 1997. Chemically induced resistance in green bean against bacterial and fungal pathogens. J. Plant Dis. Prot. 104:599610.

40. Sijam, K., Chang, C. J., and Gitaitis, R. D. 1991. An agar medium for the isolation and identification of Xanthomonas campestris pv. vesicatoria from seed. Phytopathology 81:831-834.

41. Stadnik, M. J., and Buchenauer, H. 1999 
Control of wheat diseases by a benzothiadiazole-derivative and modern fungicides. J. Plant Dis. Prot. 106:466-475.

42. Stall, R. E., and Thayer, P. L. 1962. Streptomycin resistance of the bacterial spot pathogen and control with streptomycin. Plant Dis. Rep. 46:389-392.

43. Sticher, L., Mauchmani, B., and Metraux, J. P. 1997. Systemic acquired resistance. Annu.
Rev. Phytopathol. 35:235-270.

44. Stout, M. J., Brovont, R. A., and Duffey, S. S. 1998. Effect of nitrogen availability on expression of constitutive and inducible chemical defenses in tomato, Lycopersicon esculentum. J. Chem. Ecol. 24:945-963.

45. Tosi, L., Luigetti, R., and Zazzerini, A. 1999. Benzothiadiazole induces resistance to Plasmopara helianthi in sunflower plants. J.
Phytopathol.-Phytopathol. Z. 147:365-370.

46. White, R. F. 1979. Acetylsalicylic acid (aspirin) induces resistance to tobacco mosaic virus in tobacco. Virology 99:410-412.

47. Zangerl, A. R., Arntz, A. M., and Berenbaum, M. R. 1997. Physiological price of an induced chemical defense: Photosynthesis, respiration, biosynthesis, and growth. Oecologia 109:433441. 